\title{
PARANOJA I SADYZM INSTYTUCJI. O BIESIADZIE U HRABINY KOTŁUBAJ WITOLDA GOMBROWICZA ${ }^{1}$
}

\author{
BŁAŻEJ WARKOCKI ${ }^{2}$ \\ (Uniwersytet im. Adama Mickiewicza w Poznaniu)
}

Słowa kluczowe: Gombrowicz, paranoja, masochizm, sadyzm, Deleuze Keywords: Gombrowicz, paranoia, masochism, sadism, Deleuze

\begin{abstract}
Abstrakt: Błażej Warkocki, PARANOJA I SADYZM INSTYTUCJI. O „BIESIADZIE U HRABINY KOTŁUBAJ” WITOLDA GOMBROWICZA. „PORÓWNANIA” 2 (21), 2017, S. 115-126. ISSN 1733-165X. Artykuł prezentuje „bliskie czytanie” (close reading) opowiadania Biesiada u hrabiny Kottubaj Witolda Gombrowicza z jego debiutanckiego tomu Pamiętnik z okresu dojrzewania z 1933 roku. Zasadza się na dwóch na dwóch konceptach teoretycznych: z jednej strony jest to narracja paranoiczna w znaczeniu, jakie nadała temu pojęciu Eve Kosofsky Sedgwick, a z drugiej strony - sadyzm (jako niekomplementarny w stosunku do masochizmu) w znaczeniu Gilles'a Deleuze'a (z eseju Chłód i okrucieństwo). Autor poszukuje subwersji społecznej w tej groteskowej wizji obrazów klas u Gombrowicza i odnajduje ją w sadyzmie instytucji arystokracji, która przesuwa głównego bohatera opowiadania na "pozycję paranoiczną".
\end{abstract}

\begin{abstract}
Błażej Warkocki, PARANOIA AND SADISM OF THE INSTITUTION. ON WITOLD GOMBROWICZ’S “BANQUET AT COUNTESS KOTŁUBAJ'S". "PORÓWNANIA" 2 (21), 2017, P. 115-126. ISSN 1733-165X. The article offers a close reading of Witold Gombrowicz's short story Banquet at Countess Kottubaj's from his debut collection Memoirs from a Time of Immaturity (later published under the title Bakakaj or Bacacay in the English translation). It is based on two theoretical concepts: on the one hand - a paranoid plot (according to Eve Kosofsky Sedgwick 2014), on the other hand - sadism (as non-complementary to masochism) in the sense of Gilles Deleuze (from his essay Coldness and cruelty). The author is looking for social subversion in the grotesque images of class and finds it in the sadism of the institution of aristocracy which moves the main character into a paranoid position.
\end{abstract}

1 Poszerzona i zmodyfikowana wersja tekstu ukaże się w książce: Warkocki, Błażej. Pamiętnik afektów z okresu dojrzewania. Gombrowicz - queer - Sedgwick. Poznań - Warszawa: Wydawnictwo UAM - IBL PAN, 2018.

2 E-mail: warkocki@amu.edu.pl 


\section{Ci państwo chcą mnie zjeść}

Andrzej Kijowski w swym klasycznym i przenikliwym studium Strategie Gombrowicza dostrzega rodzaj powtarzalnego scenariusza czy raczej właśnie strategii obecny w wielu utworach Witolda Gombrowicza. Jego punktem wyjścia jest bohater ze skazą, jakąś mniej lub bardziej wyrazistą innością. Dotyczyć ma to właściwie wszystkich pierwszoosobowych bohaterów opowiadan z Pamiętnika. Potem następuje śledztwo (Kijowski 441). W ogólnym zarysie tak właśnie wygląda fabuła Biesiady u hrabiny Kottubaj. Odmieniec/mieszaniec przybywa do arystokratycznego salonu, by konsumować jarskie dania. Szybko jednak zrozumie, że coś jest nie tak, jak powinno być, dystyngowane grono zachowuje się nieodpowiednio, jakby metodycznie prześladowało naszego bohatera. Ten wszczyna zatem sam dla siebie swoiste "śledztwo", aby zrozumieć, co się właściwie dzieje i jaki to ma sens. Tak rzecz wygląda od strony fabularnej.

Od strony językowej opowiadanie budowane jest natomiast wokół pola semantycznego słowa jeść. To sieć asocjacji między wyrazami w różny sposób połączonymi z czasownikiem-matką oraz ze sobą nawzajem. To swoista chmura asocjacji, która buduje efekt tego, co Michał Głowiński nazwał "fabułami językowymi” (Głowiński 24-25). Formalnie jednak jest to pole semantyczne czasownika jeść. Siłę nadaje mu jednak metafora, która się potencjalnie wyłania z tego czasownika. Chodzi o pożeranie, które jest wchłanianiem, eksploatowaniem i unicestwianiem. Pożeranie słabszych przez silniejszych, gatunki roślinożerne przez gatunki mięsożerne, klasy niższe przez klasy wyższe, gatunki ludzkie i nie-ludzkie przez kanibali swoich gatunków. Ma ono bardzo duży potencjał metaforyczny.

Spójrzmy od tej strony na Biesiadę u hrabiny Kotłubaj. Już sam tytuł eksploatuje pole semantyczne jedzenia. Po pierwsze biesiada, czyli coś więcej niż wykwintna kolacja, jedzenie połączone z dysputą, a jednocześnie dyskretne odniesienie do Uczty Platona, którego Symposion bywał spolszczany właśnie jako Biesiada. Po drugie - nazwisko Kotłubaj, które fonetycznie przywodzi na myśl kocioł a ta że dłubanie $^{3}$. Te skojarzenia były istotne w zamyśle artystycznym tekstu, pomimo że wykorzystanie nazwiska mogło skończyć się dla autora tragicznie (było bowiem autentyczne) - ponieważ wchodzi $\mathrm{w}$ zamierzone asocjacje $\mathrm{z}$ innym nazwiskiem Dróbek. To nazwisko głównego bohatera, które poznajemy dopiero w drugiej części opowiadania, właśnie wtedy zaczyna mieć bowiem znaczenie. Dróbek to mały drób, kura, którą nie tylko można zjeść, ale również ugotować w kotle. Pierwszoosobowy bohater mógłby być anonimowy, ale nie jest: jego nazwisko pojawia się późno, mianowicie wtedy, gdy ma on poczucie, że arystokratyczne towarzystwo na niego dybie, jakby chciało go zjeść. Poza tym nazwisko Dróbek ma konotować

3 Na znaczenie i „jadalność” nazwisk zwracała szczególną uwagę Ewa Graczyk (Graczyk 15). 
drobnomieszczańskie pochodzenie właściciela. Zupełnie jak nazwisko Apfelbaum ${ }^{4}$ ma kojarzyć się z pochodzeniem żydowskim. A jednocześnie, rzecz jasna, ma swój posmak „konsumpcyjny” (Apfelbaum to po niemiecku jabłoń). W tym miejscu należy przypomnieć kluczową dla opowiadania homonimię. Oto towarzystwo delektuje się nieszczególnie smacznym kalafiorem, a jednocześnie Kalafior to nazwisko chłopskiego dziecka, które błąka się w okolicy. Czy ten dobór słów ma jakiś dodatkowy sens? I czy łączenie asocjacji kulinarnych i klasowych ma znaczenie? A może nie ma żadnego? Jest wyłącznie zgrywą, żartem, grą, wyprowadzeniem czytelnika-interpretatora $\mathrm{w}$ pole?

Idźmy dalej. Hrabina znana jest z wyprawiania biesiad, to znaczy obiadów piątkowych. Piątkowych właśnie, a nie czwartkowych (czy ta zmiana w stosunku do dnia uznanego przez tradycję - oprócz tego, że piątek kojarzy się z postem - ma jakieś znaczenie?). W mniejszym gronie hrabina przyjmuje tylko niektórych gości - i tutaj zapomina się o mięsie. Mięso jest zabronione. Mięsożerność jest kojarzona jednocześnie ze stosunkami społecznymi, międzyludzkimi oraz z wyrafinowaniem i uduchowieniem. Z perspektywy Bourdieu'owskiej dystynkcji oczywiście tylko klasa uprzywilejowana może sobie pozwolić na niejedzenie mięsa - posiłku przed epoką masowej produkcji dość drogiego i rzadkiego - właśnie dlatego, że łatwo może sobie na to pozwolić, w ten sposób czyniąc zeń znak wyższości inny niż przymusowe niejedzenie mięsa przez klasy niższe, wynikłe $\mathrm{z}$ niedoborów ekonomicznych. $Z$ podobną sytuacją mamy do czynienia również wtedy, gdy baron Apfelbaum, dzięki możliwościom mowy wiązanej, omal nie powiedział przy obiedzie słowa dupa - arystokrata może grać z granicami bon tonu, czego na pewno nie powinien robić mieszczanin. Zatem mięsożerność jest rozumiana jednocześnie dosłownie i metaforycznie, podobnie jak jarskość (to jednocześnie jedzenie warzyw i duchowa lekkość).

Idźmy dalej. Nagle oczom mieszczanina Dróbka ukazuje się wielkie żarcie przy wyrafinowanym arystokratycznym stole. Ta scena ma znaczenie o tyle, że jest całkowitym złamaniem zasad bon tonu, a jednocześnie wprowadza element niepewności. Arystokracja pożera łapczywie kalafior, a jednocześnie - w tej samej scenie bohater dostrzega wystający z kieszeni egzemplarz „Kuriera Czerwonego" (tak, właśnie czerwonego) z informacją o zaginionym chłopskim dziecku Kalafiorze.

Niedługo potem otrzymujemy scenę, która wyraźnie przywodzi na myśl polowanie drapieżników na spetryfikowane ze strachu zwierzę („Widząc, że trwam w zupełnej, paralitycznej nieledwie bierności, zaczęli niby to niepostrzeżenie, coraz bliżej koło mnie krążyć, coraz wyraźniej mnie zaczepiać", Gombrowicz 2010: 106). Taki metaforyczny atak trwa aż do kulminacyjnej sceny powiązanej z omawianym polem semantycznym, czyli z tańcem kanibali. Zadręczony bohater rozpoznaje, że

4 "[N]azwisko uchodzące u nas dawniej za typowo żydowskie, podobnie jak np. Kowalski - za typowo polskie" (Gombrowicz 2002: 243). Przypis Zdzisława Łapińskiego. 
tango milonga ucztujących to $\mathrm{w}$ istocie taniec kanibali. Ktoś zatem został albo zostanie zjedzony. Czyżby bohaterowi udało się uciec przed dosłowną żarłocznością towarzystwa? Czy zamiast niego zostało zjedzone (dosłownie? metaforycznie?) chłopskie dziecko? I czy to wszystko dzieje się naprawdę, czy w wyobraźni mieszczanina Dróbka?

Ten ciąg pytań wydaje się o tyle zasadny, że uzmysławia, jak dalece mamy tu do czynienia z sytuacją paranoiczną, czy - mówiąc bardziej precyzyjnie - do jakiego stopnia bohater znajduje się, używając pojęcia Melanie Klein, w „pozycji paranoidalej" (za: Sedgwick 6). Hipoteza paranoiczna uspójnia bowiem logikę tego tekstu, jednak mamy tu do czynienia z nieco inną sytuacją narracyjną i fabularną niż w Zbrodni $z$ premedytacją. Tam sens tekstu odsłaniał się - dzięki charakterystycznej dla opowiadań detektywistycznych odwróconej narracji - w ostatnim akapicie, a obiektywny status fantazji prześladowczych również daje się dość łatwo dostrzec w miarę czytania. Innymi słowy, tekst budowany jest tak, byśmy w końcu dostrzegli, że sędzia - jak FreudowskiSchreber - ma urojenia i niebył prześladowany przez trupa ijego rodzinę.

W Biesiadzie hrabiny Kottubaj jest inaczej. Tekst budowany jest tak, żebyśmy tego nie mogli łatwo rozstrzygnąć. Przeciwnie - w całości jest opisem wyrafinowanych prześladowań przy arystokratycznym stole. Jedynym wyraźnym śladem samoświadomości paranoicznej mógłby być fragment, w którym bohater, po fatalnym przekręceniu własnego nazwiska przez hrabinę, myśli: „[...] uległem tej manii prześladowczej osobnika z niższej sfery, dopuszczonego do towarzystwa" (Gombrowicz 2010: 104). Może tak, może nie. Problem polega bowiem na tym, że - jak powiada Eve Kosofsky Sedgwick w części wstępnej do swego eseju, przywołując maksymę z lat sześćdziesiątych, którą łatwo można wygłosić pod adresem mieszczanina Dróbka - „jesteś paranoikiem, ale to nie znaczy, że nikt na ciebie nie czyha” (Sedgwick 5) bądź w wersji Henry' ego Kissingera: „nawet paranoik może mieć wrogów" (Sedgwick 5). Innymi słowy, w Biesiadzie wydaje się, co dostrzegła Ewa Graczyk (Graczyk 52), jakbyśmy mieli do czynienia z sytuacją, w której bohater znajdujący się w paranoicznej pozycji rzeczywiście jest prześladowany.

A jednak na podstawie powyżej zacytowanej maksymy nie należy dochodzić do pozornie jedynego logicznego wniosku, że „nigdy nie można być zbyt paranoicznym" (Sedgwick 5) (a jest to jeden z powodów dla których Sedgwick krytykuje współczesną jej amerykańską teorię krytyczną). Przeciwnie - łatwo bowiem można dostrzec, że czytelnik/interpretator Biesiady bez trudu może się znaleźć w pozycji, w której znajduje się bohater przy pozornie przyjaznym arystokratycznym stole (gdzie jest coraz wyraźniej atakowany kolejnymi symbolicznymi gestami). Można zatem bez końca zastanawiać się nad sensem przekręconej sylaby, znaczącego nazwiska, kolejnych połączeń w sieci asocjacji czasownika jeść. Każde z nich może mieć ważki sens - albo pośredni, albo żaden. Z każdego załamania sylaby (kottubaj potłubaj) może wyłaniać się sens będący kluczem interpretacyjnym albo też może nie mieć to żadnego znaczenia, a tym bardziej sensu. Ten kosmos bywa zwodzący - 
i to świadomie zwodzący ${ }^{5}$ - bo interpretator łatwo może dojść do wniosku, że nigdy nie sposób być dość paranoicznym.

A jednak bohater znajduje się w pozycji paranoidalnej, by raz jeszcze przywołać formułę Klein. Posługuje się nią Sedgwick w przywoływanym wcześniej eseju o charakterystycznym długim tytule Czytanie paranoiczne, czytanie reparacyjne, albo: masz paranoję i pewnie myślisz, że ten tekst jest o tobie (w oryginale aspekt retoryczny jest jeszcze wyraźniejszy: Paranoid Reading and Reparative Reading, or, You're So Paranoid, You Probably Think This Essay is About You). Ten tekst wyznaczał pewien nowy zwrot w myśleniu Sedgwick, nieco krytyczny w stosunku do obowiązujących „hermeneutyk podejrzeń", a jednocześnie poszukujący alternatywnych ścieżek wobec dominującej psychoanalizy (zwłaszcza Siegmunda Freuda i Jacques’a Lacana), czyli takiej formy myśli, która nie będzie nieustająco i petryfikująco kręcić się wokół konserwatywnie rozumianej „różnicy płciowej”. Tej fazie patronują zatem Klein i jej kategoria pozycji oraz Silvan Tomkins i jego teoria afektów.

Sedgwick adaptuje Kleinowską kategorię pozycji, bo jest labilna i potencjalnie zmienna, a zatem różni się od „normatywnie uporządkowanych faz, stabilnych struktur czy diagnostycznych typów osobowości" (Sedgwick 6). U Klein pozycja paranoiczna mieści się blisko pozycji depresyjnej i należy je rozumieć jako „zmieniające się i heterogeniczne postawy w relacjach" (Sedgwick 6). W streszczeniu Sedgwick pozycja paranoiczna wygląda tak:

Zgodnie a teorią Klein, zarówno u dziecka jak i u dorosłego, pozycja paranoidalna - naznaczona nienawiścią, niepokojem i zazdrością - charakteryzuje się ciągłym wyczuleniem na niebezpieczeństwo stwarzane przez nienawistne i zawistne obiekty częściowe, na które podmiot defensywnie projektuje swój stan, które kawałkuje i pochłania (Sedgwick 16).

Ta charakterystyka mogłaby być częściowym kluczem do interpretacji opowiadania. Każdy ruch mieszczanina przy arystokratycznym stole może być ruchem złym, odsłaniającym niskie pochodzenie. Trzeba by jednak przyjąć, że niepokój bohatera jest projektowany na arystokratyczne towarzystwo, które zachowuje się zatem dokładnie tak, jak on obawia się, że będzie się zachowywać. W związku z tym zjada po kawałku kalafior (albo Kalafiora) oraz w dalszej kolejności - potencjalnie dróbek (albo Dróbka).

A jednak na koniec tej części interpretacji warto uzupełnić je o rozważania Tomkinsa, który uznaje paranoję za przykład „silnej teorii afektu”, gdzie „teorię" należy rozumieć również jako pewien proces myślowy czy fantazję - w tym sensie, że wytwarza ją zarówno Freud, jak i jego pacjenci ${ }^{6}$. Paranoja jest również teorią afektów negatywnych. Jak pisze Sedgwick:

5 Sedgwick pisała: „Paranoja jest samoświadoma” (Sedgwick 9).

6 Freud dostrzegał (i szybko odrzucał) podobieństwo między swoją teorią a urojeniami Schrebera 
Tomkins wyróżnia kilka jakościowo różnych afektów, ale łączy je również luźno w grupy - afektów pozytywnych lub negatywnych. Przyjmując te wyznaczniki, stwierdzimy zatem, że paranoja jest nie tylko silną (a nie słabą) teorią, lecz również silną teorią negatywnego afektu (Sedgwick 15).

Mówiąc inaczej - pod paranoją kryje się układ negatywnych afektów. A dokładniej, zwłaszcza tego jednego - „silnego upokorzenia bądź strachu przed upokorzeniem” (Sedgwick 12). I nietrudno w ten sposób właśnie dekodować "teorię” (w znaczeniu Tomkinsowskim) głównego bohatera Biesiady. Inaczej rzecz ujmując - paranoiczna sytuacja Dróbka to wyrazista, wręcz krwista figura silnego strachu przed upokorzeniem.

\section{Biesiada i okrucieństwo}

Gdyby szukać głównego jądra Pamiętnika z okresu dojrzewania, to byłby nim powracający w wielu odsłonach splot paranoi i masochizmu, przy czym paranoję należy rozumieć jako pewnego rodzaju praktykę epistemologiczną (za Tomkinsem i Sedgwick), a masochizm jako coś więcej niż aktywność seksualną: swego rodzaju praktykę afektywno-kognitywną, czy nawet, jak sugeruje Gilles Deleuze - antropologiczną wizję (Leopold von Sacher-Masoch to „wielki antropolog”, Deleuze 16). Ten splot został zainicjowany w pierwszym opowiadaniu z Pamiętnika, a później był wielokrotnie rozwijany. O ile narracyjna i jakościowa zmiana motywu paranoicznego widoczna jest zwłaszcza w zestawieniu Zbrodni z premedytacją z Biesiada u hrabiny Kottubaj, to swego rodzaju dokończenie (czy też jedno z możliwych dokończeń) motywu masochistycznego z Tancerza mecenasa Kraykowskiego widać właśnie Biesiadzie.

Publicznie upokorzony przez mecenasa tancerz rozpoczyna swą mściwą krucjatę za pomocą strategii wyraźnie „niemęskich” - a zatem zamiast użycia fizycznej siły, brzydkiego mordobicia czy też eleganckiego pojedynku à la Boziewicz (takie strategie kojarzylibyśmy ze strategią stereotypowo męską) zaczyna naśladować swój obiekt, co skutkuje - używając współczesnego języka psychologii - swego rodzaju pasywną agresją. Tancerz staje się samowolnym "paziem” swego obiektu - i za pomocą tej strategii wytwarza, przynajmniej we własnym umyśle, kontrakt z mecenasem, na mocy którego wszystko, co ten może zrobić, sprawia mu

(Sedgwick 10). Schreber to oczywiście bohater klasycznej analizy Freuda, w której pojawia się teoria paranoi: Freud, Sigmund. „Psychoanalityczne uwagi o autobiograficznie opisanym przypadku paranoi (dementia paranoides)". Freud, Sigmund. Charakter a erotyka. Dzieła T. 2. Przeł. Robert Reszke, Dariusz Rogalski. Red. R. Reszke, Warszawa: Wydawnictwo KR, 1996. Tłumaczenie pamiętnika Daniela Schrebera po wielu latach ukazało się na polskim rynku: Schreber, Daniel Paul. Pamiętniki nerwowo chorego wraz z suplementami i aneksem. Tłum. Renata Darda-Staab. Kraków: Libron, 2006. 
przyjemność. Jak pokazuje Deleuze, właśnie ów kontrakt - realny bądź wyobrażony - jest niezbędnym elementem masochizmu i masochistycznej relacji ${ }^{7}$.

Z tej perspektywy spójrzmy na Biesiadę u hrabiny Kotubaj. Główny bohater przybywa na piątkowy obiad do wytwornej hrabiny. Dostaje się nawet do jeszcze bardziej elitarnego towarzystwa i miejsca, bowiem w "mniejszym salonie hrabina przyjmowała tylko szczupłą garstkę prawdziwie bliskich i zaufanych gości" (Gombrowicz 2010: 85). Dlaczego jednak nieśmiałemu mieszczaninowi przyjeżdżającemu "skromną dorożką" udało się w ogóle wejść do tego "rasowego" towarzystwa? Oczywiście dlatego, że był wyjątkowy, subtelnie myślał, a myśli swe składał $\mathrm{w}$ wiersze. A zatem już na samym początku pojawia się zarys swoistego kontraktu pomiędzy stronami, który w ogóle umożliwia kontakt. On zachowuje się skromnie i ubiera myśl w mowę wiązaną, a ona dopuszcza go do towarzystwa. Początkowo kontrakt działa, ponieważ strony przestrzegają zapisanych w nim zasad. Mieszczanin i baron licytują się na swoiste - nazwijmy rzecz po imieniu - banały wyrażane, co bardzo istotne, wierszem. Właściwe zerwanie kontraktu nastąpi wówczas, gdy towarzystwo złamie zasady obowiązującej etykiety. Zamiast jeść w sposób dystyngowany, grzeczny, małymi porcjami, nagle zacznie żreć:

[...] lecz nagle urwałem, bo nikt mnie nie słuchał! Nadzwyczajny widok hrabiny, widok dogaressy i patronessy, pożerającej w milczeniu i tak zachłannie, że aż się jej uszy trzęsły, przestraszył mnie i zdumiał. Baron sekundował jej dzielnie, pochylony nad talerzem, siorpiąc i mlaskając z całej duszy - a stara markiza usiłowała nadążyć, żując i łykając ogromne kawałki, najwidoczniej w obawie, by nie sprzątnęli jej sprzed nosa co najlepszych kąsków.

Ten niesłychany i nagły obraz żarcia - nie mogę się inaczej wyrazić - takiego żarcia, w takim domu, ten okropny przeskok, ten zmniejszony akord septymowy, do tego stopnia wstrząsnął podstawami mego jestestwa, że nie mogąc się powstrzymać - kichnąłem [...]. Ten jedynie, kto jak ja zna znał hrabinę, markizę i barona od tak dawna w wytworności ich ruchów, w delikatności, wstrzemięźliwości i subtelności ich rysów - może ocenić potworne wrażenie, jakiemu uległem. (Gombrowicz 2010: 95-96).

Ta malownicza scena przedstawia złamanie kontraktu w sensie dosłownym o tyle, o ile kontraktem jest arystokratyczny savoir-vivre jako zbiór zasad dotyczących zachowywania się przy stole, ale również - stosownych tematów rozmów. Złamanie kontraktu robi na bohaterze piorunujące wrażenie, tworząc efekt niemal paranoiczny ( $w$ tym samym momencie dostrzega on gazetę $\mathrm{z}$ informacją o zaginięciu chłopca Kalafiora, a sam znajduje się w towarzyskiej sytuacji konsumpcji

7 "In any case there is no doubt that masochism cannot do without a contract, either actual or in mind of the masochist (as in the phenomenon of pagisme)" (Deleuze 76). 
kalafiora). Trudno się mu zresztą dziwić, interpretowane wprost zachowania (jeśli uznajemy, że to nie omamy), są nie tylko złamaniem zasad savoir-vivre'u, ale również swoistym demonstracyjnym atakiem i początkiem gry w okrucieństwo.

Właśnie - okrucieństwo. Przypomnijmy, że w eseju Chłód i okrucieństwo Deleuze przekonująco rozróżnia sadyzm i masochizm jako dwa zupełnie różne przede wszystkim jednak niekomplementarne - porządki, takie, które - wbrew pozorom - nie uzupełniają się nawzajem. Są autonomiczne i niezazębiające się. Punktem wyjścia sieci różnic jest zwłaszcza ten jeden - „[...] masochista zawiązuje kontrakty, podczas gdy sadysta nienawidzi ich i je niszczy. Sadysta potrzebuje instytucji, a masochista - relacji opartej na kontrakcie" (Deleuze 20). Rozważania Deleuze'a rzucają ciekawe światło na opowiadanie Gombrowicza, ponieważ ogólna dynamika wydarzeń znakomicie rymuje się z mechanizmami zauważonymi przez francuskiego filozofa w XIX-wiecznych powieściach pisarza ze Lwowa i skontrastowana zostaje z wizją deSade'a. Tu również mieszczanin-jarosz opiera swoje funkcjonowanie w arystokratycznym towarzystwie na pewnym niepisanym kontrakcie, a arystokratyczne kółko świadomie i demonstracyjnie ten układ łamie i niszczy. Kolejne akty okrucieństwa, rzecz jasna, nie sprawiają żadnej przyjemności mieszczaninowi Dróbkowi.

W ten oto sposób cała kolejna część opowiadania polega z jednej strony na ponawianiu prób nawiązania kontaktu - poprzez przywoływanie kontraktu („Wracając do tego, co Piękne...", Gombrowicz 2010: 99), które zresztą przestaną być ponawiane (jako nieskuteczne) oraz - z drugiej strony - na demonstracyjnym złamaniu kontraktu i powielanych aktach symbolicznego okrucieństwa. Ta sadystyczna strategia jest całkowicie obca skromnemu, acz nieco paranoiczno-masochistycznemu podmiotowi, który pojawia na biesiadzie u hrabiny Kotłubaj.

Zauważmy, że w tekście nie istnieje żaden psychologiczny powód, dla którego mieszczanin mógłby zostać ukarany przez hrabinę i jej znajomych. Afekty czy nawet emocje nie odgrywają tutaj żadnej roli. Po prostu arystokratyczne kółko bez powodu, bez żadnego emocjonalnego związania czy wcześniejszej emocjonalnej inwestycji, upokarza przy stole młodego mieszczanina. Być może należy te nieistniejące powody rozumieć strukturalnie - jako dominację jednej klasy nad drugą. W tym sensie arystokratyczne kółko robi to, co robi, po prostu dlatego że może. Jednocześnie jednak ten brak emocji jest tu bardzo charakterystyczny i dostrzeżony przez Deleuze'a u wielu bohaterów de Sade'a należących do słynnych tajnych stowarzyszeń. Bohaterowie sadyczni nie potrzebują emocji, wręcz je zwalczają, całkiem inaczej niż bohaterowie Masocha - którzy potrzebują emocji oraz fantazji. Jak pisze Deleuze:

Apatia sadysty jest nade wszystko kierowana przeciw emocjom: wszystkie emocje, nawet i zwłaszcza te wynikające z czynienia zła, są zakazane, co wynika z tego, że dostarczają niebezpiecznego rozproszenia, które uniemożliwia kondensację energii i jej osad w czysty element bezosobowej i demonstracyjnej sensualności (Deleuze 62). 
Deleuze wymienia szereg cech różniących pozornie komplementarny masochizm i sadyzm, układając je w ciąg jedenastu binaryzmów. Niektóre z cech cech sadyzmu rzucają szczególnie ciekawe światło na drugą połowę opowiadania Gombrowicza, szczególnie te, które dotyczą użycia języka i schematów kompozycyjnych. Po pierwsze zatem dla sadyzmu charakterystyczne są słynne repetycje czy, jak to ujmuje francuski filozof, „ilościowe iteracje” (Deleuze 62).

A przecież wszystkie kolejne działania arystokratycznego towarzystwa to ponawiane akty symbolicznej przemocy o mniejszej lub większej sile natężenia. Od demonstracyjnego żarcia przez wskazywanie na "niskie” pochodzenie (za sprawą smaku kalafiora), "grajserowanie”, homonimie („Bug istnieje i wpada do Wisły”) po wygłosowe tango kanibalów. Działania te nie są bezpośrednio rozkazami, ale każde z nich potencjalnie wymaga reakcji z drugiej strony - reakcji, która jednak nie jest możliwa.

Wiele z tych aktów okrucieństwa dzieje się w języku i poprzez język. Hrabia zaczyna grasejować (w pierwszej części opowiadania, czyli jeszcze „przy zupie”, tego nie robi), hrabina spektakularnie myli się, zapisując swoje nazwisko dedykowane bohaterowi, potem mamy do czynienia z nonszalanckimi homonimiami. Trudno oprzeć się wrażeniu, że otrzymujemy to, co Deleuze nazwał „spekulacyjno-demonstracyjnym użyciem języka”, które opiera się na „czystej negacji”(Deleuze 62) ${ }^{8}$.

Zatem gdy bohater próbuje ratować sytuację przy stole, po raz kolejny odwołując się do kontraktu, czyli do tego, co go sprowadziło do domu hrabiny - wzniosła myśl podana w niebanalnej formie - i dopytuje się o dzieci chore na „angielską chorobę" (czyli krzywicę), którymi z daleka opiekowała się gospodyni, ta odpowiada:

A pan mówi o mich małych anglikach?... A tak, w samej rzeczy, gdy spojrzeć, jak one się niezdarnie ruszają na tych powykręcanych nożynach, jak się grzebią i przewracają, to człowiek czuje się jeszcze jary! Stary, ale jary! Dawnymi czasy jeździłam konno, w czarnej amazonce i lśniących botfortach na angielskich folblutach, a teraz - helas, les beaux temps sont passes - teraz kiedy już nie mogę, bo jestem stara, to jeżdżę sobie wesoło na moich małych powykręcanych anglikach! I nagle ręką sięgnęła w dół a ja odskoczyłem, gdyż przysięgam, chciał mi pokazać swoją starą, ale prostą, zdrową, jara jeszcze nogę! (Gombrowicz 2010: 110).

Okrucieństwo opowieści hrabiny opiera się, rzecz jasna, na homonimii. Parafrazując: hrabina ma pod swoją opieką jakiś przytułek dla dzieci chorych na angielską chorobę, krzywicę, czyli ma pod opieką ",anglików”. Kiedyś była młoda i jeździła na anglikach (czyli koniach pełnej krwi angielskiej), dziś jest stara i jeździ na swoich anglikach - dzieciach chorych na krzywicę. Mamy też dodatkowo do czynienia

8 Z kolei masochizm, ma być - wedle Deleuze'a - dialektyczno-imaginacyjny i działać poprzez mechanizm wyparcia i zawieszenia. 
z jednoczesnym znaczeniem dosłownym i metaforycznym. Fraza Jeżdże sobie wesoło może oznaczać dosłowne ujeżdżanie dzieci jak również - metaforycznie - kiedyś hrabina była młoda i poprawiała sobie humor jeżdżąc konno, a dziś - bawiąc się w filantropię. Dodatkowej dwuznaczności sytuacji dodaje słowo folblut (potoczna nazwa koni, z niemiecka: voll - 'pełny', Blut - 'krew'). Konie były bowiem pełnokrwiste, czyli rasowe, inaczej niż dzieci, które „rasowe”, pełnokrwiste zapewne nie były (jako dzieci chłopskie). Wyabstrahowany z kontekstu fragment wygląda po prostu na żart, jednak w kontekście całego opowiadania to właściwie swoiste demonstracyjne użycie homonimii oparte o radykalną negację emocjonalnej empirii (negację właśnie, a nie wyparcie, które ma być charakterystyczne dla masochizmu).

$\mathrm{W}$ tej samej ramie należy rozumieć jedną $\mathrm{z}$ ostatnich scen, znaną $\mathrm{z}$ tego, że zawiera banalną (ale okrutną) homonimię. Przypomnijmy:

- Ależ Bóg, Bóg istnieje! - wyjąkałem w końcu, ostatkiem sił, szukając na gwałt jakiejś ostoi - Bóg istnieje - dodałem ciszej - gdyż imię Boskie rozległo się tak nie a propos, że nastąpiło milczenie i na twarzach ukazały się wszelkie złowróżebne oznaki, zwiastujące nietakt - i czekałem tylko, kiedy ukażą mi się drzwi!

- A tak - odparł po chwili baron de Apfelbaum, druzgocąc mię w proch nieporównanym taktem - Bug? Bug istnieje - i wpada do Wisły! (Gombrowicz 2010: 111).

Bohater po raz ostatni, beznadziejnie, nawiązuje do kontraktu - uruchamiając tematykę wzniosłej dykcji, którą wyraża się mową wiązaną - i przywołuje najwyższą instancję. W zamian otrzymuje szyderczą - jakkolwiek w typie witty talk homonimię. Jest to demonstracyjne (w znaczeniu Deleuze'a) użycie języka, mające na celu upokorzenie naszego bohatera (z czego ten doskonale zdaje sobie sprawę). To kluczowy w opowiadaniu moment deziluzji. Nie ma kontraktu, jest sadyzm.

A sadyzm - powiada Deleuze w Chłodzie i okrucieństwie - potrzebuje instytucji, działa poprzez instytucje. Bohaterowie świętego markiza to przecież najczęściej tajne koła, stowarzyszenia libertarian, które dokonują okrutnych rytuałów, jak w 120 dniach Sodomy. Nie inaczej jest przecież w Biesiadzie u hrabiny Kottubaj:

My arystokracja - markiza dobrotliwie nachyliła się do mnie - hołdujemy wielkiej swobodzie obyczajów w najściślejszym kółku, a wówczas, jak pan to może słyszał, używamy nawet czasami gruboskórnych wyrażeń i bywamy frywolni, a nierzadko i swoiście ordynarni. Ale nie trzeba się raza przerażać! Trzeba się z nami oswoić! (Gombrowicz 2010: 99).

Gdyby zatem zapytać o potencjał krytyczny opowiadania, o ewentualną społeczną subwersję, to odpowiedź mogłaby brzmieć: tak, ona istnieje. I chodziłoby w niej przede wszystkim o wyeksponowanie nie tyle - po Marksowsku - ucisku klasowego, co raczej - po Deleuzjańsku - swoistego sadyzmu „instytucji”, poprzez który działa arystokracja. Koniec końców w tym duchu streszczał wymowę tekstu sam 
młody gniewny Gombrowicz w Krótkim objaśnieniu: „Sens noweli zasadza się na tem, że głód i cierpienia biednego Bolka Kalafiora dodaja smaku arystokratom, jedzącym kalafiora - jarzynę. Tajemnicą, której tak długo nie domyśla się mój humanitarny jarosz, jest naturalne okrucieństwo wszelkie arystokracji" (Gombrowicz 1933: 6).

A jednak opowiadanie kończy się charakterystycznym wątkiem w paranoidalnym duchu. Można by go zdiagnozować, za Sedgwick, jako male paranoid plot: męska fabuła paranoiczna, do której wgląd daje nam Freudowski przypadek Schrebera, a która miała duże znaczenie w Zbrodni z premedytacją i będzie mieć również spore znaczenie w Zdarzeniach na brygu Banbury. Młody upokorzony mieszczanin dostrzega, że doborowe arystokratyczne towarzystwo po wyśmienitej kolacji zabiera się do - całkiem naturalnego w tej sytuacji - tańca. Ma to być tango milonga, dystyngowane, choć z pewnym queerowym zapleczem, a bohater widzi w tym układzie ruchów zupełnie coś innego: „taniec kanibali”. Widzi zatem coś, co mu zagraża, co go pochłonęło, co sugeruje nieprzyjemny współudział i co - koniec końców - może go zjeść.

\section{BIBLIOGRAFIA}

Deleuze, Gilles. "Coldness and Cruelty". Masochism. Gilles Deleuze "Coldness and Cruelty" and Leopold von Sacher Masoch "Venus in Furs". Przeł. Jean McNeil. Nowy Jork: Zone Books, 1991. S. 9-138.

Freud, Sigmund. „Psychoanalityczne uwagi o autobiograficznie opisanym przypadku paranoi (dementia paranoides)". Freud, Sigmund. Charakter a erotyka. Dzieła T. 2. Przeł. Robert Reszke, Dariusz Rogalski. Red. R. Reszke. Warszawa: Wydawnictwo KR, 1996. S. 105-176.

Głowiński, Michał. Gombrowicz i nadliteratura. Kraków: Wydawnictwo Literackie, 2002.

Gombrowicz, Witold. „Biesiada u hrabiny Kotłubaj”. Gombrowicz, Witold. Bakakaj i inne opowiadania. Kraków: Wydawnictwo Literackie, 2010. S. 84-113.

Gombrowicz, Witold. Pamiętnik z okresu dojrzewania. Warszawa: Towarzystwo Wydawnicze „Rój”, 1933. Graczyk, Ewa. Przed wybuchem wstrząsnać. O twórczości Witolda Gombrowicza w okresie międzywojennym. Gdańsk: słowo/obraz / terytoria, 2004.

Kijowski, Andrzej. „Strategia Gombrowicza”. Gombrowicz i krytycy. Wybór i opracowanie Z. Łapiński. Kraków - Wrocław: Wydawnictwo Literackie, 1984. S. 429-465.

Schreber, Daniel Paul. Pamiętniki nerwowo chorego wraz z suplementami i aneksem. Przeł. Renata Darda-Staab. Kraków: Libron, 2006.

Sedgwick, Kosofsky Eve. „Czytanie paranoiczne, czytanie reparacyjne, albo: masz paranoję i pewnie myślisz, że ten tekst jest o tobie". Przeł. Magda Szcześniak. Widok. Teorie i praktyki kultury wizualnej 5 (2014). S. 1-36. 
